\title{
ANALISIS KANDUNGAN KARBOHIDRAT TERLARUT TOTAL PLANLET BAYAM MERAH [Alternanthera amoena (Lem.) Voss] RESISTEN TERHADAP CEKAMAN GARAM (NaCl) SECARA IN VITRO
}

\author{
Endang Nurcahyani ${ }^{1,2}$ Dian Pratiwi ${ }^{2 *}$, Zulkifli $^{2}$, Martha L. Lande ${ }^{2}$ \\ ${ }^{1}$ Prodi Biologi Terapan, Fakultas MIPA, Universitas Lampung Bandar Lampung, 35145 \\ ${ }^{2}$ Prodi Biologi, Fakultas MIPA, Universitas Lampung Bandar Lampung, 35145 \\ endang.nurcahyani@fmipa.unila.ac.id
}

\begin{tabular}{|l|}
\hline $\begin{array}{l}\text { Artikel Info } \\
\text { Diterima } \\
\text { tanggal } \\
\text { 06. 06.2021 }\end{array}$ \\
$\begin{array}{l}\text { Disetujui } \\
\text { publikasi } \\
\text { tanggal } \\
19.10 .2021\end{array}$ \\
Kata kunci : \\
$\begin{array}{l}\text { Bayam merah, } \\
\text { cekaman garam, } \\
\text { in vitro, planlet }\end{array}$
\end{tabular}

kandungan karbohidrat planlet bayam merah pada kondisi cekaman garam secara in vitro.

\begin{abstract}
ABSTRAK
Bayam merah [Alternanthera amoena (Lemaire) Voss.] banyak digemarioleh masyarakat karena kandungan nutrisinya yang bermanfaat seperti melancarkan peredaran darah, menurunkan tekanan darah tinggi dan kolesterol, sehingga produksi terakumulasi oleh garam termasuk Indonesia. Salah satu alternatif yang dapat digunakan yaitu dengan penggunaan varietas bayam merah yang toleran terhadap merah dalam mengahadapi cekaman garam secara in vitro. Metode yang digunakan Rancangan Acak Lengkap (RAL) dengan 5 taraf konsentrasi $\mathrm{NaCl}$ yaitu $0 \%$; way ANOVA pada taraf 5\% dan uji lanjut dengan uji Tukey pada taraf nyata $5 \%$. Hasil penelitian menunjukkan bahwa perlakuan $\mathrm{NaCl}$ berpengaruh pada karakter ekspresi planlet bayam merah seperti menurunnya tinggi tanaman dan peningkatan
\end{abstract}

\begin{abstract}
Red spinach [Alternanthera amoena (Lemaire) Voss.] is popular because of its beneficial nutritional content, such as improving blood circulation, lowering high blood pressure and cholesterol, so that the production of red spinach must be optimized. Currently, a lot of agricultural land is accumulated by salt, including Indonesia. One alternative that can be used is the use of red spinach varieties that are tolerant of salt stress. This study aims to determine the effective concentration of $\mathrm{NaCl}$ on the growth of red spinach plantlets and the character of red spinach expression in dealing with salt stress in vitro. The method used was a completely randomized design (CRD) with 5 levels of $\mathrm{NaCl}$ concentration of $0 \%$; $0.25 \%$; $0.50 \%$; $0.75 \%$ and $1 \%$ with 5 repetitions. Data analysis used one way ANOVA at the 5\% level and further tests with Tukey's test at the 5\% real level. The results showed that the $\mathrm{NaCl}$ treatment had an effect on the expression characters of red spinach plantlets such as a decrease in plant height and an increase in the carbohydrate content of red spinach plantlets under salt stress conditions in vitro.
\end{abstract}




\section{PENDAHULUAN}

Tanaman bayam merah [Alternanthera amoena (Lem.) Voss] berasal dari Amerika Tropik, pada mulanya dikenal sebagai tanaman hias, namun seiring dengan perkembangan zaman, tanaman ini dimanfaatkan sebagai bahan pangan yang kaya akan protein, vitamin A, B, C, mengandung garam-garam mineral, kalium, fosfor dan besi (Nirmalayanti dkk., 2017). Bayam merah termasuk jenis tanaman hortikultura yang dikembangkan di Indonesia karena beberapa faktor yang sesuai untuk pertumbuhannya seperti iklim, cuaca dan tanah. Ciri khusus dari jenis bayam merah adalah adanya kandungan antosianin yang merupakan pigmen ungu merah yang membuat daun bayam memiliki warna merah (Pebrianti dkk., 2015). Banyaknya kandungan nutrisi dan khasiatnya dalam mengobati berbagai penyakit, maka pertumbuhan dan produksi bayam merah perlu dioptimalkan (Setiawati dkk., 2018).

Total luas lahan rawa di Indonesia diperkirakan mencapai 33.393.570 ha dengan kriteria luas lahan rawa pasang surut yaitu 20.096.800 ha (60,2\%) dan lahan rawa lebak 13.296.770 ha $(39,8 \%)$ (Pusat Data Rawa Indonesia, 2018). Cekaman garam menyebabkan proses fisiologis dan biokimia tanaman seperti toksisitas ion dan cekaman air. Terdapat beragam jenis garam yang dapat mempengaruhi salinitas tanah. Salah satu senyawa garam yang paling dominan dan mudah larut dalam tanah adalah $\mathrm{NaCl}$ (Natrium klorida) (Tavakkoli et al., 2010).

Perkembangan bioteknologi yang dapat digunakan untuk memperbaiki karakter serta ketahanan suatu tanaman yaitu dengan menggunakan teknik in vitro. Teknik kultur jaringan dapat menghasilkan bibit yang banyak dengan sifat yang dikehendaki dan tanaman yang bebas penyakit (Yusnita, 2015). Tingkat keberhasilan pada teknik kultur jaringan bergantung pada sumber eksplan dan jenis media . Macam-macam eksplan yang dapat digunakan yaitu pucuk, daun, akar, biji , tunas, kotiledon, hipokotil, buah serta bakal buah (Henuhili, 2013). Sedangkan medium yang digunakan harus mengandung unsur makro, mikro, vitamin dan zat pengatur tumbuh. Medium Murashige and skoog (MS) paling banyak digunakan dalam kultur jaringan (Fauzy et al., 2016).

Karbohidrat merupakan senyawa yang terdiri atas unsur $\mathrm{C}, \mathrm{H}$ dan $\mathrm{O}$ dengan rumus kimia yaitu $\mathrm{C}_{\mathrm{n}}\left(\mathrm{H}_{2} \mathrm{O}\right)_{\mathrm{n}}$ atau $\mathrm{C}_{\mathrm{n}} \mathrm{H}_{2 \mathrm{n}} \mathrm{O}_{\mathrm{n}}$. Selulosa mendominasi karbohidrat yang berasal dari tumbuhtumbuhan hampir mencapai 50\%, hal ini dikarenakan selulosa bagian yang terpenting dari dinding sel tumbuh-tumbuhan (Wiratmaja et al., 2011). Kandungan karbohidrat digunakan 
sebagai parameter dalam analisis dasar biosains. Terdapat berbagai macam karbohidrat yaitu sukrosa, glukosa dan fruktan. Kandungan karbohidrat terlarut pada tumbuhan dapat mempertahankan kelangsungan hidup terhadap kondisi cekaman (Masuko et al., 2005). Penelitian mengenai kandungan karbohidrat terlarut total sudah pernah dilakukan pada Buncis (Nurcahyani dkk., 2019a), kacang panjang (Nurcahyani, 2019b) yang tercekam kekeringan secara in vitro

\section{METODE}

\section{Alat dan Bahan}

Alat-alat yang digunakan dalam penelitian ini adalah autoclave, Erlenmeyer, Beaker glass, alumunium foil, tabung reaksi, rak tabung reaksi, gelas ukur, Laminar Air Flow (LAF), corong gelas, mortar, pestle, tissue, pinset, pipet tetes, neraca analitik, plastik, kertas label, botol kultur, spektofotometer, penggaris, oven, kuvet dan pipet ukur.

Bahan-bahan yang digunakan adalah benih bayam merah (Alternanthera amoena Voss.) dari varietas Mira dengan merek dagang cap Panah Merah, kertas filter Whatman No.1, glukosa, akuades, alkohol 96\%, agar, spritus, fenol, medium Murashige and koog (MS) padat, Natrium klorida $(\mathrm{NaCl})$, Kalium hidroksida $(\mathrm{KOH})$, Asam klorida $(\mathrm{HCl})$ dan Asam sulfat $\left(\mathrm{H}_{2} \mathrm{SO}_{4}\right)$

\section{Prosedur}

\section{Pembuatan medium tanam}

Pembuatan medium tanam MS sebanyak 1 liter dengan cara menimbang medium dasar Murashige and Skoog use ready sebanyak 4,43 gram kemudian dimasukkan kedalam labu takar 1 liter. Setelah itu ditambahkan aquades sampai mencapai batas 1 liter dan $\mathrm{pH}$ larutan diatur hingga 5,5 dengan cara penambahan $\mathrm{KOH} 1 \mathrm{~N}$ atau $\mathrm{HCl} 1 \mathrm{~N}$. Lalu larutan dipindahkankedalam wadah yang lebih besar dan ditambahkan agar-agar sebanyak $7 \mathrm{~g} / \mathrm{L}$ serta sukrosa sebanyak $30 \mathrm{~g} / \mathrm{L}$. Selanjutnya larutan dipanaskan dengan hot plate dan diaduk rata hingga mendidih. Setelah itu larutan di tuangkan kedalam botol kultur sebanyak $20 \mathrm{ml}$ dan dilakukan penambahan $\mathrm{NaCl}$ dengan berbagai konsentrasi yaitu $0 \%, 0,25 \%, 0.50 \%, 0,75 \%$ dan $1 \%$ pada tiap perlakuan. Kemudian botol-botol yang sudah berisi medium di sterilisasi menggunakan autoclave dan diinkubasi selama 7 hari pada suhu kamar $\left(25^{\circ} \mathrm{C}\right)$ untuk memastikan medium bebas dari kontaminasi. 


\section{Sterilisasi biji bayam merah}

Sterilisasi biji bayam merah dilakukan dalam Laminar Air Flow (LAF) dengan cara merendam biji selama 5 menit, setelah memasukkan dalam larutan bayclin 10\% selama 2-3 menit (Ashari dkk., 2018). Benih dibilas dengan akuades steril dengan pengulangan sebanyak 3 kali dan di pindahkan ke dalam cawan petri steril. Setiap botol kultur ditanami 10 biji, sehinggaterdapat 250 biji bayam dalam 25 botol. Biji bayam merah ditumbuhkan hingga menjadi planlet.

\section{Analisis kandungan karbohidrat}

Analisis kandungan karbohidrat dilakukan dengan menggunakan metode fenolsulfur (Dubois, 1956). Batang dan daun planlet ditimbang sebanyak 0,1 gram kemudian ditumbuk dengan mortar, setelah itu ditambahkan aquades sebanyak $10 \mathrm{ml}$. Setelah itu larutan disaring menggunakan kertas Whatman No. 1 dan dimasukkan dalam tabung reaksi. Kemudian filtrat diambil sebanyak $1 \mathrm{ml}$ dan ditambahkan $\mathrm{H}_{2} \mathrm{SO}_{4}$ sebanyak $1 \mathrm{ml}$, fenol sebanyak $2 \mathrm{ml}$. Setelahitu filtrat dimasukkan dalam kuvet. Dilakukan pembacaan serapan dengan spektrofotometer UV pada panjang gelombang $490 \mathrm{~nm}$.

\section{HASIL DAN PEMBAHASAN}

Salinitas menimbulkan masalah bagi tanaman melalui tiga cara yaitu (1) cekaman kekeringan karena meningkatnya tekanan osmotik air, (2) keracunan ion $\mathrm{Cl}^{-}$dan $\mathrm{Na}^{+}$karena konsentrasi yang berlebihan dan (3) ketidakseimbangan unsur hara akibat penghambatan penyerapan hara, serta kombinasi dari faktor-faktor tersebut (Purwaningrahayu dan Taufiq, 2017). Penggunaan $\mathrm{NaCl}$ digunakan untuk menyeleksi tanaman yang tumbuh dalam kondisi cekaman garam. Pemberian $\mathrm{NaCl}$ dengan konsentrasi 0\%, 0.25\%, 0.50\%, 0.75\% dan $1 \%$ dalam medium MS (Murashige and Skoog) dapat menyeleksi dan menujukkan karakter ekspresi planlet bayam merah [Alternanthera amoena (Lemaire) Voss.] yang tumbuh pada cekaman garam.

Kandungan karbohidrat digunakan sebagai parameter dalam analisis dasar biosains. Terdapat berbagai macam karbohidrat yait;u sukrosa, glukosa dan fruktan. Kandungan karbohidrat terlarut pada tumbuhan dapat mempertahankan kelangsungan hidup terhadap kondisi cekaman (Masuko etal.,2005). Kandungan karbohidrat memiliki peran dalam mengatur tekanan potensial air pada kondisi cekaman kekeringan. Kandungan karbohidrat dapat diamati pada organ batang karena banyak mengandung konsentrasi gula dan menunjukkan karakterisasi perubahan genotip pada kondisi tercekam (Kerepesi dan Galiba, 2000) 


\section{Tinggi Planlet}

Hasil uji homogenitas ragam menggunakan uji Levene dengan pemberian $\mathrm{NaCl}$ berbagai konsentrasi disajikan pada Tabel 1.

Tabel 1. Efek perlakuan tinggi planlet bayam merah terhadap $\mathrm{NaCl}$ padaberbagai konsentrasi

\begin{tabular}{cc}
\hline Konsentrasi NaCl $(\% \mathrm{~b} / \mathrm{v})$ & Tinggi Planlet $(\mathrm{cm})^{\overline{\mathrm{Y}} \pm \mathrm{SE}}$ \\
\hline 0 & $5.94 \pm 0.34^{\mathrm{a}}$ \\
0.25 & $6.00 \pm 0.37^{\mathrm{a}}$ \\
0.50 & $4.86 \pm 0.21^{\mathrm{a}}$ \\
0.75 & $5.20 \pm 0.25^{\mathrm{a}}$ \\
1.00 & $4.34 \pm 0.19^{\mathrm{bc}}$ \\
\hline
\end{tabular}

\section{Keterangan:}

Nilai-nilai yang diikuti oleh huruf yang sama tidak berbeda nyata pada taraf nyata $5 \%$ Tinggi planlet $=\hat{Y} \pm$ SE

$\bar{Y}=$ Nilai rata-rata tinggi planlet $\mathrm{SE}=$ Standar error

Cekaman salinitas terhadap bayam merah dapat mempengaruhi sifat agronomis tanaman, seperti tinggi tanaman. Terganggunya pertumbuhan tanaman disebabkan oleh adanya cekaman osmotik yang menyebabkan tanaman sulit menyerap air sehingga pembelahan dan pembesaran sel terhambat (Romadloni dan Wicaksono, 2018). Penurunan tinggi tanaman juga disebabkan oleh tingginya kandungan garam terlarut dalam tanah salin, terutama ion $\mathrm{Na}+$, yang menyebabkan menurunnya ketersediaan unsur $\mathrm{Ca}, \mathrm{Mg}$, dan $\mathrm{K}$ yang merupakan unsur esensial yang dibutuhkan tanaman (Wahyuningsih et al., 2017).

\section{Analisis Karbohidrat}

Hasil uji homogenitas ragam menggunakan uji Levene dengan pemberian berbagai konsentrasiNaCl dsajikan pada Tabel 2.

Tabel 2. Efek perlakuan $\mathrm{NaCl}$ terhadap kandungan karbohidrat terlarut total bayam merah 28 hari setelah tanam

\begin{tabular}{cc}
\hline Konsentrasi $\mathrm{NaCl}(\% \mathrm{~b} / \mathrm{v})$ & Karbohidrat Terlarut Total $(\mathrm{mg} / \mathrm{L})$ \\
$\overline{\mathrm{Y}} \pm \mathrm{SE}$ \\
\hline 0 & $30.95 \pm 6.28^{\mathrm{a}}$ \\
0.25 & $33.37 \pm 1.43^{\mathrm{a}}$ \\
0.50 & $38.85 \pm 2.91^{\mathrm{a}}$ \\
0.75 & $54.79 \pm 2.47^{\mathrm{bc}}$ \\
1.00 & $44.04 \pm 3.75^{\mathrm{ac}}$ \\
\hline
\end{tabular}




\section{Keterangan:}

Nilai-nilai yang diikuti oleh huruf yang sama tidak berbeda nyata pada taraf nyata 5\%

Karbohidrat $=\hat{Y} \pm$ SE

$\bar{Y}=$ Nilai rata-rata karbohidrat

$\mathrm{SE}=$ Standar error

Korelasi antara konsentrasi $\mathrm{NaCl}$ dengan panjang akar planlet bayam merah ditunjukkanpada

\section{Gambar 2.}

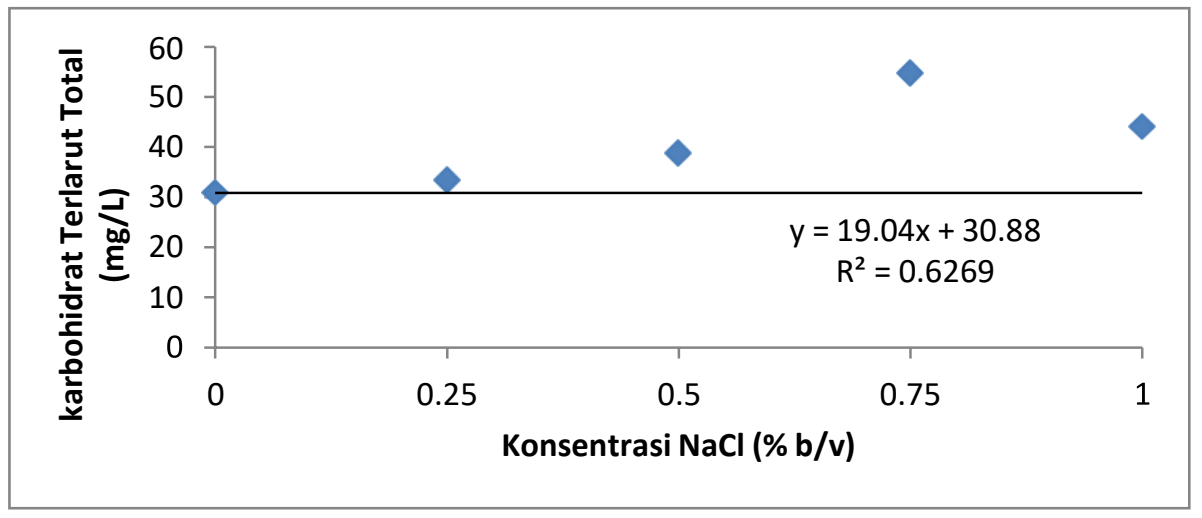

\section{Gambar 2. Kurva regresi konsentrasi $\mathrm{NaCl}$ dan karbohidrat terlaruttotal planlet bayam merah}

Berdasarkan Gambar 2. kurva rerata karbohidrat terlarut total mengalami peningkatan tertinggi pada perlakuan $\mathrm{NaCl} 0.75$. Hal ini menunjukkan bahwa cekaman salinitas memiliki berbagai efek pada ekspresi gen metabolisme sukrosa. Osmoregulasi adalah aspek kunci dalam toleransi salinitas pada tanaman dan beberapa osmolit utama seperti prolin, gula dan poliol yang memiliki peran penting dalam mengurangi cekaman salinitas sehingga menyebabkan peningkatan kadar gen metabolisme gula (Nahar et al., 2016). Peningkatan kandungan karbohidrat yang terjadi pada tanaman merupakan upayauntuk bertahan pada kondisi cekaman kekeringan (Nurcahyani dkk., 2019a).

\section{KESIMPULAN}

Berdasarkan hasil penelitian yang telah dilakukan dapat disimpulkan bahwa $\mathrm{NaCl}$ memberikan pengaruh nyata terhadap tinggi planlet dan kandungan karbohidrat planlet bayam merah pada kondisi cekaman garam secara in vitro. 


\section{DAFTAR PUSTAKA}

Ashari, A., Nurcahyani,E., Hardoko I.Q., dan Zulkifli, 2018, Analisis Kandungan Prolin Planlet Jeruk Keprok Batu 55 (Citrus Reticulata Blanco Var. Crenatifolia) Setelah Diinduksi Larutan Atonik dalam Kondisi Cekaman Kekeringan Secara In Vitro. Analit: Analytical and Environmental Chemistry. 3(01):69-78.

Dubois, M., K.A. Gille, J.K Hamilton, P.A. Rebers, dan Smith, F, 1956, Colometri method for Determination of sugars and Related Subtance, Anal. Biochem., 28(1956):143-145.

Fauzy, F., Mansyur., A. Husni, 2016, Pengaruh Penggunaan Media Murashige dan Skoog (Ms) dan Vitamin Terhadap Tekstur, Warna dan Berat Kalus Rumput Gajah (Pennisetum purpureum) CV. Hawaii Pasca Radiasi Sinar Gamma pada Dosis Ld50 (In Vitro), EJournal Student., 5 (4): 1-22.

Henuhili, V., 2013, Kultur Jaringan Tanaman, UNY Press, Yogyakarta.

Kerepesi, I., dan G. Galiba., 2000, Osmotic and Salt Stress-Induced Alteration in Soluble Carbohydrate Content in Wheat Seedlings. Crop Science 40(2000): 482-487.

Masuko, T., Minami, A., Norimasa, I, Majima, Tokifumi., Nishimura, S dan Lee, Y., 2005, Carbohydrate Analysis by a Phenol-Sulfuric Acid Method inMicroplate Format, Analitical Biochemistry., 339 (2005): 69-72.

Nahar K, Hasanuzzaman M, and Fujita M., 2016, Roles of osmolytes in plant adaptation to drought and salinity. In N. Iqbal, N. A. Khan, and R. Nazar (Eds.), Osmolytes and Plants Acclimationto Changing Environment: Emerging Omics Technologies (pp. 37-68). Springer. https://doi.org/10.1007/978-81-322-2616-1

Nirmalayanti, K.A., 2017, Peningkatan Produksi dan Mutu Tanaman Bayam Merah (Amaranthusamoena Voss) Melalui Beberapa Jenis Pupuk pada Tanah Inceptisols, Desa Pegok, Denpasar, PS Agroekoteknologi Tropika., 6 (1): 1-10.

Nurcahyani E, Mutmainah NA, Farisi S, dan Agustrina R., 2019a, Analisis Kandungan Karbohidrat Terlarut Total Planlet Buncis (Phaseolus vulgaris L.) Menggunakan Metode Fenol-Sulfur Secara In Vitro, Anali., 4 (1): 73-80.

Nurcahyani E, Sazilly MR, Farisi S, dan Agustrina R., 2019b, Efek Inokulasi Rhizoctonia solanii Terhadap Kandungan Karbohidrat Terlarut Total Planlet Kacang Panjang (Vigna unguiculata (L.) Walp.) Secara In Vitr, Analit., 4 (1): 81-90.

Pebrianti, C., Ainurrasjid, A., and Purnamaningsih, S. L., 2015, Uji kadar antosianin dan hasil enamvarietas tanaman bayam merah (Alternanthera Amoena Voss) pada musim hujan, Jurnal Produksi Tanaman., 3 (1): 27-33. 
Purwaningrahayu, R. D. dan A. Taufiq., 2017, Respon morfologi empat genotip kedelai terhadap cekaman salinitas, Jurnal Biologi Indonesia., 13 (2): 175 - 188.

Pusat Data Rawa Indonesia., 2019. Pusat Data dan Informasi Rawa dan Pesisir. http://www.pusdatarawa.or.id/tentang-pusat-data-rawa/Diakses 18 Januari 2021.

Romadloni, A., K. P. Wicaksono., 2018, Pengaruh beberapa level salinitas terhadap perkecambahan kacang hijau (Vigna radiata L.) varietas Vima 1, Jurnal Produksi Tanaman., 6 (8): 1663 - 1670.

Setiawati, T ,Rahmawati, F,. dan Supriatun,T., 2018, Pertumbuhan Tanaman Bayam Cabut (Amaranthus tricolor L.) dengan Aplikasi Pupuk Organik Kascing dan Mulsa Serasah Daun Bambu, Jurnal Ilmu Dasa., 19 (1): 1-8.

Tavakkoli, E., Rengasamy, P., and McDonald, G. K., 2010, High concentrations of Na+ and $\mathrm{Cl}$-ions in soil solution have simultaneous detrimental eff ects on growth of faba bean undersalinity stress, Journal of Experimental Botany., 61(15):4449-4459.

Wahyuningsih, S., A. Kristiono, A. Taufiq., 2017, Pengaruh jenis amelioran terhadap pertumbuhan dan hasil kacang hijau di tanah salin, Buletin Palawija., 15 (2): 69 77.

Wiratmaja IG, Wijaya Kusuma IGB, \& Winaya Suprapta IN, 2011, Pembuatan Etanol Generasi Kedua dengan Memanfaatkan Limbah Rumput Laut (Euchema cattonii) sebagai Bahan Baku, Jurnal Ilmiah Teknik Mesin., 5 (1): 75-84.

Yusnita, 2015, Kultur Jaringan Tanaman Sebagai Teknik Penting Bioteknologi Untuk Menunjang Pembangunan Pertanian. In Penerbit Aura Publishing. 